\title{
Enhanced Overwintering Survival of Stevia by Qol Fungicides Used for Management of Sclerotium rolfsii
}

\author{
A. M. Koehler and H. D. Shew, Department of Entomology and Plant Pathology, North Carolina State University, Raleigh 27695
}

\begin{abstract}
Stevia (Stevia rebaudiana) is a herbaceous perennial under evaluation as a new crop in the southeastern United States. Stem rot caused by Sclerotium rolfsii is common in stevia plantings in North Carolina, with symptoms including wilting, root and stem necrosis, and plant death. Fungicide efficacy trials for management of $S$. rolfsii were conducted over 2 years. Fungicides evaluated included azoxystrobin, flutolanil, and tebuconazole applied at three timings. Azoxystrobin applied to transplants 1 week prior to planting had the lowest area under the disease progress curve values across all trials. Fungicide plots were also used to evaluate overwintering of stevia. End-of-season stand counts were

compared with spring emergence counts to quantify overwintering survival. In spring 2015, plots treated with azoxystrobin in 2014 had greater overwintering survival $(78 \%)$ than other fungicide treatments $(38 \%)$ and the control (38\%). Similar results were obtained at two locations in spring 2016 in plots treated with azoxystrobin or pyraclostrobin in 2015. Successful overwintering of stevia directly impacts the profitability of second- and third-year harvests and enhances the likelihood of longterm establishment of stevia as a viable crop. Future studies will be directed at elucidating the mechanism of the enhanced overwintering survival of plants treated with quinone outside inhibitor fungicides.
\end{abstract}

Stevia rebaudiana (Bertoni) Bertoni is a herbaceous perennial native to Paraguay emerging as a new crop in the United States. $S$. rebaudiana is a member of the Asteraceae family with leaves that contain multiple diterpene glycosides extracted for use as a natural, noncaloric sweetener (Kinghorn 2003). Commercial production of stevia began in Paraguay in 1964 and spread to Japanese markets in the 1970s (Carakostas et al. 2008; Katayama et al. 1976). The United States Department of Agriculture approved stevia for use as a nonnutritive sweetener in December 2008 (Food and Drug Administration Generally Recognized as Safe Notice GRN 000253 and GRN 000252). Following approval, the U.S. market for stevia rapidly grew as companies expanded their low-calorie products. To meet the demand of increasing commercial products utilizing stevia glycosides, there has been a growing interest in establishing stevia as a crop in the United States.

Due to favorable climate, high levels of natural rainfall, and existing infrastructure, North Carolina has been a leading state to evaluate the viability of producing stevia in the United States. Stevia plantings in North Carolina began in 2011 and commercial acreage has continued to expand slowly. In current production practices, stevia is started from seed in a greenhouse float tray system and plants are transplanted to the field 8 to 10 weeks later, typically from late April to late May. Production practices, including planting date, plant density, row spacing, and nutritional inputs, have yet to be optimized for production in the southeast. Stevia is a short-day plant with a native range between latitudes of 23 and $24^{\circ} \mathrm{S}$, with aerial temperatures ranging from -6 to $43^{\circ} \mathrm{C}$ (Yadav et al. 2011). Stevia field sites in North Carolina are located between latitudes 35 and $36^{\circ} \mathrm{N}$. Day length is somewhat longer at these latitudes compared with the native range for stevia, which is desirable for glycoside accumulation. However, these latitudes also mean cooler winter temperatures that may limit stevia's ability to be grown as a perennial. Determining whether stevia overwinters well in North Carolina is vital to establishing stevia as a viable commodity. At frost, aboveground portions of the plant die back and roots and crowns overwinter. If plants successfully overwinter, abundant new shoots begin to emerge in March, typically

Corresponding author: A. M. Koehler; E-mail: amkoehle@ncsu.edu

Accepted for publication 25 April 2017.

(c) 2017 The American Phytopathological Society allowing two harvests per growing season in the second and third years of production.

Because stevia can be grown as a perennial, it is being investigated as a rotation crop in traditional and organic systems, as an organic transition crop, and as a tobacco replacement crop. Stevia germplasm was screened against major tobacco pathogens that would limit successful rotation with tobacco. Stevia was not a host for the most severe pathogens, including Phytophthora nicotianae, Ralstonia solanacearum, and Tobacco mosaic virus, indicating its potential as a tobacco rotation option (A. M. Koehler and A. J. Mendoza-Moran, unpublished).

Abundant wilting and death of plants was observed in first- and second-year commercial plantings of stevia in 2012 and 2013. Koch's postulates verified Sclerotium rolfsii as the causal agent (Koehler and Shew 2014). There are currently no fungicides or biological controls labeled for stevia in the United States; therefore, efficacious and economically feasible approaches to disease management are needed. $S$. rolfsii produces abundant sclerotia capable of surviving long periods in soil. Without management tools, high inoculum accumulation over the 3- to 5-year production cycle of a stevia crop may become a limiting factor to the expansion of commercial production of stevia in North Carolina as well as to other crops grown in rotation with stevia. $S$. rolfsii is particularly devastating to stevia because it quickly kills entire plants, single or multistem.

In May 2014, a preliminary trial was established in Kinston, NC to screen azoxystrobin, flutolanil, and tebuconazole efficacy for management of $S$. rolfsii. The first fungicide applications occurred 3 weeks after planting. By this time, $S$. rolfsii incidence had already reached $20 \%$ across the field. Diseased plants were examined and hyphae and sclerotia were found on the roots and stems of seedlings. This trial demonstrated that $S$. rolfsii was able to rapidly colonize stevia roots and stems and indicated the importance of a fungicide application at planting for successful disease management (Koehler and Shew 2015).

In addition to keeping plants disease free during the season, fungicides may also improve the health and vigor of plants entering the overwintering period. Because stevia cannot be direct seeded into the field using current practices and the cost associated with crop establishment is the most expensive part of producing stevia, successful overwintering of stevia crowns into second- and third-year crops is critical to the long-term profitability and ultimate establishment of stevia as a crop in North Carolina.

The objectives of this project were to (i) identify fungicides and early-season application timings for control of $S$. rolfsii on stevia and (ii) assess the ability of stevia to overwinter in North Carolina; 
and (iii) based on spring observations from initial fungicide trials where some fungicide treatments had greater overwintering survival than control plots, determine whether fungicide applications consistently enhance overwintering survival of stevia.

\section{Materials and Methods}

Fungicide timing trials. Fungicide application timing trials were conducted at the Caswell Research Farm $\left(35^{\circ} 27^{\prime} \mathrm{N}, 77^{\circ} 61^{\prime} \mathrm{W}\right)$ in Kinston, NC in 2014 and 2015. Stevia rebaudiana was originally planted at this site in 2012 and high levels of disease caused by Sclerotinia rolfsii were observed in first-year plants. The stevia crop was removed in May 2013 and soybean was grown. In July 2014, 10week-old seedlings of the commercial line G7 of Stevia rebaudiana were planted at a density of 43,000 plants $\mathrm{ha}^{-1}$ with a row spacing of 0.76 m on flat rows (trial 1). Due to the high inoculum levels of Sclerotinia rolfsii naturally present in the soil, no additional inoculum was added to the test site. The test was repeated in two adjacent field locations in 2015, with plantings in May and July (trials 2 and 3).

Treatments were arranged in a randomized complete block design with two 7.62-m rows in each of five replicates per treatment. Treatments included three fungicides-azoxystrobin (Abound; Syngenta Crop Protection, Inc., Greensboro, NC), flutolanil (Convoy; Nichino America, Inc., Wilmington, DE), and tebuconazole (Folicur; Bayer Crop Science, Research Triangle Park, NC), each applied at three different timings - and a nontreated control. The fungicides used in this study were chosen to represent different modes of action effective against $S$. rolfsii in other crops. The three fungicides used were azoxystrobin, a quinone outside inhibitor (QoI); flutolanil, a succinate dehydrogenase inhibitor; and tebuconazole, a demethylation inhibitor. All of these fungicides are available at a cost per application that would fit the projected economics of stevia production in the southeast. Treatment timings included a foliar application applied to transplants in the greenhouse 1 week before planting, incorporation in transplant water at planting, and a foliar spray applied directly after planting (Table 1). Fungicide timings were selected to test the feasibility of various early-season application methods and screen for phytotoxicity because observations in 2014 had indicated that stem rot developed very early in the season, soon after transplanting. Foliar sprays were banded over rows using a TeeJet TP8006 flat-fan nozzle on a $\mathrm{CO}_{2}$ sprayer calibrated to deliver product in $\mathrm{H}_{2} \mathrm{O}$ at a rate of 280.6 liters ha ${ }^{-1}$. All of the treatments, excluding the control, also received a foliar spray of their corresponding fungicide at rates of azoxystrobin at $381 \mathrm{~g}$ of active ingredient (a.i.) ha ${ }^{-1}$, flutolanil at $1.06 \mathrm{~kg}$ a.i. ha ${ }^{-1}$, or tebuconazole at $229 \mathrm{~g}$ a.i. ha ${ }^{-1} 3$ weeks after planting using the $\mathrm{CO}_{2}$ sprayer.

Table 1. Treatment list for field experiments examining the effect of fungicide and application timing for management of stem rot of stevia caused by Sclerotium rolfsii

\begin{tabular}{lc}
\hline Treatments, application timingy & Rate (a.i. g/ha) \\
\hline Azoxystrobin & \\
Transplant spray & 381 \\
Transplant water & 381 \\
Foliar spray & 381 \\
Flutolanil & \\
$\quad$ Transplant spray & 1,065 \\
Transplant water & 1,065 \\
Foliar spray & 1,065 \\
Tebuconazole & \\
Transplant spray & 229 \\
Transplant water & 229 \\
$\quad$ Foliar spray & 229 \\
\hline y Transplant sprays were applied to seedlings in the greenhouse 1 week prior \\
to planting. Treated plants remained in the greenhouse until the time of \\
planting. Transplant water treatments were mixed into planting water and \\
the tank was rinsed between each fungicide application. Foliar spray treat- \\
ments were applied immediately after transplant. \\
z Active ingredient in grams per hectare.
\end{tabular}

Disease incidence and statistical analysis. In each of the three fungicide trials, disease incidence was evaluated for 41 to 43 days following planting for a total of four disease evaluations in each trial. Disease incidence in trial 1 was evaluated 6, 20, 29, and 41 days after planting (DAP). Disease incidence was evaluated 5, 19, 29, and 43 DAP in trial 2 and 13, 22, 29, and 41 DAP in trial 3. A plant was counted as diseased if leaves and stems were permanently wilted and had stem bleaching and necrosis. Stand counts of healthy plants were taken at each assessment date and divided by the original number of plants within the plot to obtain the percentage of healthy plants remaining. Healthy plants were counted because diseased seedlings quickly degraded and were no longer visible for rating. Percent healthy plants were then subtracted from a possible total of $100 \%$ healthy plants to obtain disease incidence for each plot. Using the mean percent disease at each rating date, area under the disease progress curve (AUDPC) values were calculated for all treatments in each trial using the trapezoidal method $A=\Sigma_{i=1}^{N_{i}-1}\left(\frac{y_{i}+y_{i+1}}{2}\right)\left(t_{i+1}-t_{i}\right)$. AUDPC values were standardized using the equation standardized AUDPC $=($ AUDPC/D), where $D$ is the time span in days for AUDPC. Data from experiments were pooled across location for analysis. Combined AUDPC data from the three replicated experiments were subjected to mixed-model analysis of variance (ANOVA) using PROC GLIMMIX in SAS (version 9.4) There was no significant interaction between trial and treatment; thus, all trials were analyzed together. Treatment was treated as a fixed effect and trial, replication, and the overall error term were treated as random effects. Fixed effects were tested for significance at $\alpha=0.05$ and significant differences among treatment means were separated using paired $t$ tests.

Overwintering. Four overwintering trials were conducted over a 2 -year period. Plants from the three fungicide trials described above were left in the field to establish overwintering trials at latitude $35^{\circ}$ $27^{\prime} \mathrm{N}$. The Kinston soil type is a Stallings loamy sand (coarseloamy, siliceous, semiactive, thermic aeric paleaquult). A fourth overwintering site was established in 2015 further north at the Upper Coastal Plain Research Station $\left(35^{\circ} 89^{\prime} \mathrm{N}, 77^{\circ} 68^{\prime} \mathrm{W}\right)$ in Rocky Mount, NC. The soil type in this field is a Wagram loamy sand (loamy, kaolinitic, thermic arenic kandiudult).

After taking final stand counts for the 2014 and 2015 fungicide trials, plants were mowed at a height of approximately $10 \mathrm{~cm}$, leaf and stem debris were removed from the field to simulate harvest, and plants were left in the field to overwinter. Daily aerial high and low temperatures along with high and low soil temperatures at a depth of $0.1 \mathrm{~m}$ were tracked during the coldest months of the year (December through February) using data from the Lower Coastal Plain Research Station (http://climate.ncsu.edu/cronos/?station= KINS) (Table 2). In trial 1, emergence rates were counted on 14 April and 4 May 2015. In trial 2, emergence rates were collected on 19 April and 24 May 2016. In trial 3, emergence rates were collected on 19 April.

At the Rocky Mount location, 10-week-old seedlings of the commercial line G3 of Stevia rebaudiana were planted at a density of

Table 2. Average aerial and soil high and low temperatures from December to February ${ }^{\mathrm{y}}$

\begin{tabular}{llllrr}
\hline & \multicolumn{4}{c}{ Temperature $\left({ }^{\circ} \mathbf{C}\right)$} \\
\cline { 2 - 3 } \cline { 5 - 6 } & \multicolumn{2}{c}{ Aerial } & & \multicolumn{2}{c}{ Soil } \\
\cline { 2 - 3 } \cline { 5 - 6 } Location, year & High & Low & & High & Low \\
\hline Kinston 2014-15 & 10.9 & 0.3 & & 9.6 & 8.3 \\
Kinston 2015-16 & 14.3 & 4.3 & & 12.7 & 11.2 \\
Rocky Mount 2015-16 & 13.4 & 3.4 & & 11.1 & 7.3 \\
\hline
\end{tabular}

y Aerial temperatures were measured at a height of $2 \mathrm{~m}$ and soil temperatures at a depth of $0.1 \mathrm{~m}$

${ }^{\mathrm{z}}$ Kinston trials were planted on flat rows at $0.71-\mathrm{m}$ row spacing in soil classified as coarse-loamy, siliceous, semiactive, thermic aeric paleaquults. The Rocky Mount trial was planted on raised rows at $0.91-\mathrm{m}$ row spacing in a loamy, kaolinitic, thermic arenic kandiudults soil. 
72,000 plants $\mathrm{ha}^{-1}$ on bedded rows with a spacing of $0.91 \mathrm{~m}$ on 1 June 2015 (trial 4). This field site did not have a history of Sclerotium rolfsii; thus, the effect of late-season fungicide applications on overwintering survival could be tested. The objective of this trial was to test a second QoI fungicide in addition to azoxystrobin and apply both at different timings only toward the end of the season to observe their effects on overwintering. Treatments were arranged in a randomized complete block design with four 12.2-m rows and six replicates per treatment. Treatments included azoxystrobin (Abound; Syngenta Crop Protection, Inc.) and pyraclostrobin (Headline; BASF Corporation, Research Triangle Park, NC) applied at one of three timings, and a nontreated control. Treatment timings included one application prior to harvest (19 August), two applications prior to harvest (19 August and 2 September), and one application before harvest and one application after harvest (19 August and 11 October) for each fungicide. Azoxystrobin was applied at a rate of $381 \mathrm{~g}$ a.i. $\mathrm{ha}^{-1}$ and pyraclostrobin at a rate of $403 \mathrm{~g}$ a.i. ha ${ }^{-1}$ using the $\mathrm{CO}_{2}$ sprayer, as described above. At the end of the growing season, final stand counts were taken, plants were mowed at a height of approximately $10 \mathrm{~cm}$ to simulate harvest, leaf and stem debris were removed from the field, and plants were left in the field to overwinter. Daily aerial high and low temperatures at a height of $2 \mathrm{~m}$ along with high and low soil temperatures at a depth of $0.1 \mathrm{~m}$ were tracked from December through February using weather data from the Upper Coastal Plant Research Station (http://climate.ncsu.edu/cronos/?station=ROCK) (Table 2). In trial 4, emergence rates were counted on 30 April and 16 May 2016. While counting emergence on 16 May, the number of stems emerging from each plant was counted. A subplot harvest of second-year plants in trial 4 was conducted on 16 July 2016 by harvesting 3.05-m-long sections of the center two rows of each four-row plot.

Overwintering survival and statistical analysis. In each of the four overwintering trials, final spring stand counts were compared with stand counts from the end of the previous season to determine the percentage of plants that successfully overwintered. Trials 1 and 3 were planted in July and trials 2 and 4 were planted in May; therefore, each trial was analyzed separately. In trials with stand count ratings at two dates (trials 1,2, and 4), the percentage of plants emerged at the earlier date out of the total plants emerged for the season was calculated. In trial 4 , the emerging stems per plant were counted and yield data were calculated by converting subplot harvest weights to kilograms of leaf weight per hectare. Mixed-model ANOVA was conducted using PROC GLIMMIX in SAS (version 9.4). Data from each trial were analyzed with treatment treated as a fixed effect and replication treated as a random effect. Fixed effects were tested for significance at $\alpha=0.05$ and LSmeans were separated using paired $t$ tests.

\section{Results}

Fungicide timing trials. Environment. Environmental conditions were favorable for disease in all three fungicide trials. In trial 1, the average daily high aerial temperature was $29.7^{\circ} \mathrm{C}$, with night temperatures averaging $20.4^{\circ} \mathrm{C}$. Over the 41 -day period, plants received $24.7 \mathrm{~cm}$ of natural rainfall and no supplemental irrigation. Of the total rainfall, $9.6 \mathrm{~cm}$ fell within the final 3 days of the trial. In trial 2, the daily average high temperature was $32.3^{\circ} \mathrm{C}$, with night temperatures of $21.3^{\circ} \mathrm{C}$. Over the 43 -day trial, there was $14.9 \mathrm{~cm}$ of natural rainfall spread evenly over the growing season. In trial 3 , the daily high was $31.1^{\circ} \mathrm{C}$, with night temperatures of $20.3^{\circ} \mathrm{C}$. Over the 41-day, trial there was $12.3 \mathrm{~cm}$ of natural rainfall.

$A U D P C$ ratings. Three fungicide products were tested using three different timing-of-application treatments. Symptomatic plants were visible within 1 week of planting and mean disease in control treatments reached $26 \%$ by 41 DAP in trial $1,14 \%$ by 43 DAP in trial 2 , and $42 \%$ by 41 DAP in trial 3 . There was no interaction between trial and treatment $(P<0.2751)$; therefore, all trials were analyzed together. There were significant treatment effects $(P<0.03)$ and, among the nine treatments evaluated, three treatments had significantly lower AUDPC values compared with the control (Table 3). None of the treatments, including the transplant water treatments, resulted in phytotoxicity to stevia. Transplant water treatments of azoxystrobin reduced disease. Tebuconazole applied as a preplant treatment to transplants 1 week before planting reduced disease but tebuconazole applied as a foliar spray at planting had the highest AUDPC values across all trials. Azoxystrobin applied as a preplant treatment to transplants 1 week prior to planting had the lowest AUDPC values across all trials (Table 3).

Overwintering. Overwintering environment. The 2014-15 winter had below-normal temperatures from December to February but soil temperatures at $0.1 \mathrm{~m}$ did not go below freezing. The lowest soil temperatures were $8.9^{\circ} \mathrm{C}$ in December, $5.33^{\circ} \mathrm{C}$ in January, and $2.6^{\circ} \mathrm{C}$ February. The 2015-16 winter had above-normal temperatures from December to February at both field sites. In trials 2 and 3, soil temperatures remained above freezing at a depth of $0.1 \mathrm{~m}$ and December and February temperatures were warmer than 2014-15. The lowest soil temperatures in trials 2 and 3 reached $12^{\circ} \mathrm{C}$ in December, $5.1^{\circ} \mathrm{C}$ in January, and $4.6^{\circ} \mathrm{C}$ in February. In trial 4 at the Rocky Mount location, soil temperatures were lower than Kinston in the 2014-15 and 2015-16 winter. The lowest soil temperatures at $0.1 \mathrm{~m}$ reached $5.6^{\circ} \mathrm{C}$ in December, $1.2^{\circ} \mathrm{C}$ in January, and $0.5^{\circ} \mathrm{C}$ in February.

Overwintering survival. Across all trials and treatments at the Kinston location, overwintering survival ranged from 16.8 to $88.1 \%$. Final spring emergence was determined on 4 May 2015 for trial 1, 24 May 2016 for trial 2, and 19 April 2016 for trial 3. The planting date and earlier rating date for trial 3 led to significant trial effects $(P<$ $0.0001)$ and a trial-treatment interaction $(P=0.05)$; therefore, each trial was analyzed separately. In each trial, there were significant treatment effects $(P<0.0001)$ (Table 4$)$. In all trials, azoxystrobin treatments had significantly higher overwintering emergence than other fungicide treatments or the nontreated control (Table 4). In trial 1 , azoxystrobin treatments had a mean overwintering survival rate of $77.9 \%$ compared with flutolanil treatments $(44.1 \%)$, tebuconazole treatments $(31.1 \%)$, and the nontreated control $(37.6 \%)$. In trial 2 , mean overwintering survival rate of the azoxystrobin treatments was $80.7 \%$ compared with flutolanil treatments $(52.1 \%)$, tebuconazole treatments $(51.8 \%)$, and the nontreated control $(53.2 \%)$. In trial 3 , mean azoxystrobin overwintering survival rates were $59.9 \%$ compared with flutolanil treatments $(23.4 \%)$, tebuconazole treatments (24.3\%), and the nontreated control (16.8\%). Within azoxystrobin treatments in trials 1 and 3, overwintering survival was highest in plants that were sprayed 1 week prior to planting.

Table 3. Effects of fungicide products and application method on area under disease progress curves for stem rot of stevia caused by Sclerotium rolfsii

\begin{tabular}{lc}
\hline Treatments $^{\mathbf{y}}$ & SAUDPC $\pm \mathbf{S E}$ \\
\hline Nontreated & $12.7 \pm 2.0 \mathrm{bc}$ \\
Azoxystrobin & \\
$\quad$ Transplant spray & $5.5 \pm 1.3 \mathrm{a}$ \\
Transplant water & $6.5 \pm 0.9 \mathrm{a}$ \\
$\quad$ Foliar spray & $9.3 \pm 2.4 \mathrm{abc}$ \\
Flutolanil & \\
$\quad$ Transplant spray & $9.8 \pm 1.8 \mathrm{abc}$ \\
Transplant water & $8.3 \pm 1.3 \mathrm{ab}$ \\
Foliar spray & $8.3 \pm 1.1 \mathrm{ab}$ \\
Tebuconazole & \\
Transplant spray & $7.0 \pm 1.0 \mathrm{a}$ \\
Transplant water & $8.0 \pm 1.4 \mathrm{ab}$ \\
Foliar spray & $13.4 \pm 3.1 \mathrm{c}$ \\
Pr $>F$ & 0.03 \\
\hline
\end{tabular}

${ }^{y}$ Fungicides were applied according to application method at or before planting and as a foliar spray 3 weeks following planting.

${ }^{\mathrm{z}}$ Standardized area under disease progress curve $(\mathrm{SAUDPC}) \pm$ standard error (SE). AUDPC was calculated using the trapezoidal method and data were standardized by dividing by the duration of the epidemic. Data from three trials was combined and analyzed using the PROC GLIMMIX procedure in SAS (version 9.4); LSmeans were separated using paired $t$ tests $(\alpha=$ $0.05)$. Treatments followed by the same letter are not significantly different. 
In addition to having higher mean overwintering survival rates, plants in the azoxystrobin treatments also emerged earlier than those in other fungicide treatments or the nontreated control plants. When comparing emerged plants of trial 1 on 14 April to the total emerged at 4 May, there were significant treatment effects $(P<0.0001)$. In azoxystrobin treatments, $80.4 \%$ of the total plants that successfully overwintered had emerged by 14 April whereas only $48.1 \%$ of plants treated with flutolanil, $41.8 \%$ of plants treated with tebuconazole, and $32.5 \%$ of nontreated control plants had emerged. In 2016, when comparing emerged plants on 19 April and 24 May, significant treatment effects were again observed $(P<0.0001)$. In azoxystrobin treatments, $94.5 \%$ of plants that successfully overwintered had emerged by 19 April compared with $70.2 \%$ of plants treated with flutolanil, $64.5 \%$ of plants treated with tebuconazole, and $65 \%$ of control plants.

In trial 4 at the Rocky Mount location, mean overwintering survival was 58.4 to $94.2 \%$ across treatments. There were no significant

Table 4. Effect of fungicide applications during the growing season on emergence of stevia stems from overwintering crowns the following spring in Kinston, $\mathrm{NC}$

\begin{tabular}{|c|c|c|c|}
\hline \multirow[b]{3}{*}{ Fungicide treatmenty } & \multicolumn{3}{|c|}{ Overwintering emergence ${ }^{x}$} \\
\hline & Trial 1 & Trial 2 & Trial 3 \\
\hline & $\overline{4 \text { May } 2015}$ & $\overline{24 \text { May } 2016}$ & 19 April 2016 \\
\hline Nontreated & 37.6 cde & $53.2 \mathrm{~b}$ & $16.8 \mathrm{~b}$ \\
\hline \multicolumn{4}{|l|}{ Azoxystrobin } \\
\hline Transplant spray & $88.1 \mathrm{a}$ & $81.0 \mathrm{a}$ & $65.3 \mathrm{a}$ \\
\hline Transplant water & $74.1 \mathrm{ab}$ & $87.9 \mathrm{a}$ & $58.2 \mathrm{a}$ \\
\hline Foliar spray & $71.6 \mathrm{~b}$ & $73.1 \mathrm{a}$ & $56.1 \mathrm{a}$ \\
\hline \multicolumn{4}{|l|}{ Flutolanil } \\
\hline Transplant spray & $43.3 \mathrm{~cd}$ & $49.6 \mathrm{bc}$ & $18.0 \mathrm{~b}$ \\
\hline Transplant water & $49.1 \mathrm{c}$ & $49.8 \mathrm{~b}$ & $26.5 \mathrm{~b}$ \\
\hline Foliar spray & 39.9 cde & $56.9 \mathrm{~b}$ & $25.7 \mathrm{~b}$ \\
\hline \multicolumn{4}{|l|}{ Tebuconazole } \\
\hline Transplant spray & 35.4 cde & $55.2 \mathrm{bc}$ & $18.0 \mathrm{~b}$ \\
\hline Transplant water & $24.1 \mathrm{e}$ & $59.7 \mathrm{~b}$ & $27.5 \mathrm{~b}$ \\
\hline Foliar spray & $33.9 \mathrm{de}$ & $40.5 \mathrm{c}$ & $27.5 \mathrm{~b}$ \\
\hline $\operatorname{Pr}>F^{\mathrm{z}}$ & $<0.0001$ & $<0.0001$ & $<0.0001$ \\
\hline
\end{tabular}

x Trials were planted on 29 July 2014 (trial 1), 28 May 2015 (trial 2), and 28 July 2015 (trial 3). Spring stand counts were taken for each trial and compared with the number of plants alive before winter to determine the percentage of plants that overwintered. Data were analyzed using PROC GLIMMIX in SAS (version 9.4); LSmeans were separated using paired $t$ tests $(\alpha=0.05)$. Treatments followed by the same letter are not significantly different.

${ }^{y}$ Fungicide treatments were applied in the previous growing season.

${ }^{z}$ Treatment effect within each trial.

Table 5. Effect of fungicide applications in 2015 on spring 2016 emergence of stevia stems from overwintering crowns in Rocky Mount, NC

\begin{tabular}{|c|c|c|}
\hline Fungicide treatment & Dates of application & Emergence ${ }^{y}$ \\
\hline Nontreated & & $58.4 \mathrm{~b}$ \\
\hline \multicolumn{3}{|l|}{ Azoxystrobin } \\
\hline $\begin{array}{l}\text { Once before and once } \\
\text { after harvest }\end{array}$ & 19 August and 11 October 2015 & $92.2 \mathrm{a}$ \\
\hline Twice before harvest & 19 August and 2 September 2015 & $88.5 \mathrm{a}$ \\
\hline Once before harvest & 19 August & $91.6 \mathrm{a}$ \\
\hline \multicolumn{3}{|l|}{ Pyraclostrobin } \\
\hline $\begin{array}{l}\text { Once before and once } \\
\text { after harvest }\end{array}$ & 19 August and 11 October & $93.5 \mathrm{a}$ \\
\hline Twice before harvest & 19 August and 2 September 2015 & $94.1 \mathrm{a}$ \\
\hline Once before harvest & 19 August & $86.0 \mathrm{a}$ \\
\hline $\operatorname{Pr}>F^{\mathrm{z}}$ & $\ldots$ & $<0.0001$ \\
\hline
\end{tabular}

y Overwintering emergence 16 May 2016. Spring stand counts were conducted for each trial and compared with the number of plants alive before winter to determine the percentage of plants that successfully overwintered. Data were analyzed using PROC GLIMMIX in SAS (version 9.4); LSmeans were separated using paired $t$ tests $(\alpha=0.05)$. Treatments followed by the same letter are not significantly different.

${ }^{\mathrm{z}}$ Treatment effect within trial. differences among the six QoI fungicide treatments. All azoxystrobin and pyraclostrobin treatments had significantly higher overwintering emergence than the nontreated control whether they were applied before or after harvest. $(P<0.0015$; Table 5$)$. When comparing emerged plants on 30 April to the total emerged by 16 May, there were no significant treatment differences. On 30 April, $88 \%$ of total plants had emerged in azoxystrobin treatments, $85 \%$ of total plants had emerged in pyraclostrobin treatments, and $76 \%$ of total plants had emerged in the control. Total stems of each plant were counted and there were no significant treatment differences. Azoxystrobin treatments averaged 9 stems/plant and pyraclostrobin treatments averaged 10 stems/plant whereas the control averaged 5 stems/plant. There were no treatment differences in the weights of subplot harvests of trial 4 .

\section{Discussion}

S. rolfsii is an important disease of stevia that causes wilting and death of whole plants. Because stevia is grown as a perennial crop, inoculum buildup of sclerotia in the soil could be a limiting factor to the expansion of stevia production in North Carolina. Symptoms of infection by $S$. rolfsii can be observed shortly after planting in first-year crops or soon after emergence of stems from overwintering crowns. The optimal aerial temperature for growth of $S$. rolfsii has been reported as 27 to $30^{\circ} \mathrm{C}$ but disease can develop at or just below $20^{\circ} \mathrm{C}$ (Aycock 1966). In this study, and in grower fields where this disease has been observed, plantings are completed between May and July. Soil temperatures are favorable during this time period and disease may begin shortly after seedlings are transplanted. Average soil temperature in all Kinston trials was 28 to $28.5^{\circ} \mathrm{C}$ for the duration of the growing season. Stem rot was observed during the first week after planting and progressed steadily through the growing season in all trials. Trial 3 had the highest disease incidence due to greater sclerotia levels in that portion of the field because of prior planting of susceptible hosts, including stevia and soybean.

Azoxystrobin and tebuconazole all had efficacy for the management of stem rot of stevia caused by $S$. rolfsii. These fungicides have been shown to be efficacious for management of $S$. rolfsii in peanut production (Mehan et al. 1994; Rideout et al. 2002). We observed that $S$. rolfsii is able to rapidly infect both roots and stems of stevia, which stresses the importance of having preventative fungicide treatments available for use in stevia production. Once dried, the sclerotia of $S$. rolfsii can eruptively germinate following exposure to volatile compounds. Volatiles from peanut tissue, alfalfa hay, methanol, isopropyl, and butyl alcohols have been documented to stimulate sclerotial germination (Beute and Rodriguez-Kabana 1979; Linderman and Gilbert 1969; Punja et al. 1984; Rodriguez-Kabana et al. 1980). Volatiles produced by stevia may be responsible for the rapid disease development

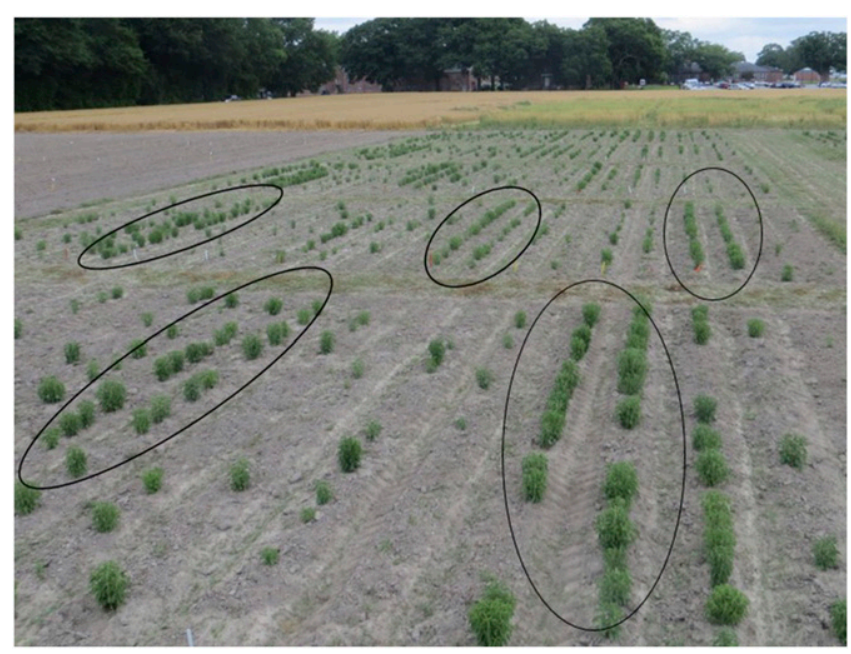

Fig. 1. Differences in overwintering emergence. Plots treated with quinone outside inhibitor (Qol) fungicides are indicated in black circles (not all Qol-treated plots are circled). 
observed in the field trials. Additional studies are needed to understand the interaction between stevia roots and sclerotial germination.

We observed significant levels of disease suppression with three of the treatments applied before or at transplant. Azoxystrobin was the only fungicide applied as a transplant water treatment with significantly lower AUDPC values. This application method provides better protection to the root system of young transplants because this product is an acropetal penetrant and foliar sprays are unlikely to provide root protection. Azoxystrobin applied to transplants 1 week prior to planting had the lowest AUDPC. In a previous trial, we observed that azoxystrobin was less effective when applied after an epidemic has initiated, which supports the importance of early application for optimum azoxystrobin efficacy (Koehler and Shew 2015). Flutolanil was not efficacious in any of the treatment methods tested. Tebuconazole had efficacy as a transplant treatment applied prior to planting but did not perform well as a foliar spray application. We exceeded the recommended spray interval for tebuconazole of 2 weeks by waiting until 3 weeks after transplanting to reapply the product. This delay may have resulted in lower efficacy than what may have occurred with a more frequent application of the fungicide.

In addition to surviving disease in the initial growing season, overwintering survival of stevia will be critical to the profitability and establishment of stevia as a new crop. Stevia plants successfully overwintered at two locations between latitudes of 35 to $36^{\circ} \mathrm{N}$ in this study. Plants remained dormant belowground from the first frost in the fall, when shoots were killed, until emergence the following spring between March and mid-May. Multiple factors, including location, planting date, and fungicide treatment, affected the percentage of plants that overwintered in this study. Despite Rocky Mount having lower soil temperatures, stevia growth rates and mean overwintering survival were higher in the Wagram loamy sand at Rocky Mount $\left(35^{\circ} 89^{\prime} \mathrm{N}\right)$ than the coarser Stallings loamy sand at the Kinston field site $\left(35^{\circ} 27^{\prime} \mathrm{N}\right)$. More work is needed to understand the role of soil factors on crown weight, yield potential, and overwintering survival of stevia.

In the four trials reported here, plants were transplanted at two seasonal timings. Plants in tests transplanted in May (trials 2 and 4) had higher survival rates than plants in the tests planted in July (trials 1 and 3). At the Kinston site, control plants that were transplanted in May (trial 2) had an overwintering survival rate of 53.2\% compared with $37.6 \%$ and $16.8 \%$ for plants that were transplanted in July (trials 1 and 3). In Rocky Mount, control plants transplanted in May had a survival rate of $58.4 \%$. Growers have made similar observations on the effects of late planting on overwintering survival (A. M. Koehler, unpublished). First-year plants must be transplanted after the danger of last frost but delaying planting past May will greatly reduce the ability of plants to survive and become established as a perennial crop. This is especially important for growers, because there are no establishment costs for seedlings in second- and third-year crops if most plants survive the winter. The primary effect of early planting is thought to be on plant vigor, because early planting gives the plants a longer time to grow and produce large root systems that aid in overwintering.

Interestingly, the factor that had the greatest effect on survival of plants was application of the QoI fungicides azoxystrobin or pyraclostrobin. This enhanced survival was observed over two winters in all four trials, and also with applications that ranged from early in the season, before or at transplant, to those specifically set up to be late in the season, close to or after harvest. In spring 2015, plants treated with azoxystrobin had significantly higher overwintering emergence than other fungicide treatments or the nontreated control (Fig. 1). A second field site at higher latitude was established in 2015 to test azoxystrobin and a second QoI fungicide, pyraclostrobin. In spring 2016, all QoI fungicide treatments had higher overwintering emergence than other fungicides or nontreated controls. Enhanced overwintering due to QoI fungicide application occurred regardless of season planted, soil type, plant variety, and differing culture practices, including flat versus raised-bed planting. At the Kinston site, in addition to an enhanced rate of survival, plants treated with azoxystrobin also emerged earlier than plants treated with other fungicides. More vigorous growth early in the spring may allow these plants to grow larger overall and produce more biomass earlier in the season, which would increase yields for at least the first harvest for second- and third-year plants. At the Rocky Mount site, significant emergence differences may have been observed if the preliminary stand count was collected earlier in the season. In trial 4, stems from each treatment were counted and plants receiving applications of azoxystrobin or pyraclostrobin had more emerging stems per plant, which also has potential to increase yields for the first harvest. Although there were no significant treatment differences in the subplot harvest of trial 4 due to variability in plots, QoI treatments had an average harvest weight of $973 \mathrm{~kg} / \mathrm{ha}$ compared with $484 \mathrm{~kg} / \mathrm{ha}$ in the nontreated control.

Several studies have looked at physiological effects of QoI fungicides and their effects on yield and biomass of annual crops but little or no work has been completed on perennial plants such as stevia (Grossmann and Retzlaff 1997; Nelson and Meinhardt 2011; Swoboda and Pedersen 2009). The mechanism of this enhanced survival is not known, and will require extensive soil and root sampling in future studies to determine whether the effect is on control of root-inhabiting fungi or on plant physiological systems.

\section{Acknowledgments}

We thank the North Carolina Tobacco Trust Fund Commission, the North Carolina Tobacco Foundation, Inc., and The R.J. Reynolds Tobacco Company for their financial support of this project; Sweet Green Fields and U.S. Stevia, LLC for providing plants for use in all studies; and the field staff of the Caswell Research Center and Upper Coastal Plain Research Station for their excellent assistance with land and equipment used in these trials.

\section{Literature Cited}

Aycock, R. 1966. Stem rot and other diseases caused by Sclerotium rolfsii or the status of Rolf's fungus after 70 years. N. C. Agric. Exp. Stn. Tech. Bull 174.

Beute, M., and Rodriguez-Kabana, R. 1979. Effect of wetting and the presence of peanut tissues on germination of sclerotia of Sclerotium rolfsii produced in soil. Phytopathology 81:1293-1296.

Carakostas, M., Curry, L., Boileau, A., and Brusick, D. 2008. Overview: the history, technical function and safety of rebaudioside A, a naturally occurring steviol glycoside, for use in food and beverages. Food Chem. Toxicol. 46: S1-S10.

Grossmann, K., and Retzlaff, G. 1997. Bioregulatory effects of the fungicidal strobilurin kresoxim-methyl in wheat (Tritium aestivum). Pestic. Sci. 50:11-20.

Katayama, O., Sumnida, T., Hayashi, H., and Mitsuhashi, H. 1976. The Practical Application of Stevia and Research and Development Data. I.S.U. Co., Tokyo.

Kinghorn, A. D. 2003. Stevia: The Genus Stevia. Taylor and Francis, New York

Koehler, A., and Shew, H. 2014. First report of stem and root rot of Stevia caused by Sclerotium rolfsii in North Carolina. Plant Dis. 98:1005.

Koehler A. and Shew H. D. 2015. Evaluation of Abound, Convoy, and Folicur for stem rot control on stevia in North Carolina, 2014. Plant Dis. Manage. Rep. 9: V102.

Linderman, R., and Gilbert, R. 1969. Stimulation of Sclerotium rolfsii in soil by volatile components of alfalfa hay. Phytopathology 59:1366-1372.

Mehan, V., Mayee, C., and McDonald, D. 1994. Management of Sclerotium rolfsii-caused stem and pod rots of groundnut-A critical review. Int. J. Pest Manage. 40:313-320.

Nelson, K. A., and Meinhardt, C. 2011. Foliar boron and pyraclostrobin effects on corn yield. Agron. J. 103:1352-1358.

Punja, Z., Jenkins, S., and Grogan, R. 1984. Effect of volatile compounds, nutrients, and source of sclerotia on eruptive sclerotial germination of Sclerotium rolfsii. Phytopathology 74:1290-1295.

Rideout, S. L., Brenneman, T. B., and Culbreath, A. K. 2002. Peanut disease management utilizing an in-furrow treatment of azoxystrobin. Online publication. Plant Health Prog. doi:10.1094/PHP-2002-0916-01-RS

Rodriguez-Kabana, R., Beute, M., and Backman, P. 1980. A method for estimating numbers of viable sclerotia of Sclerotium rolfsii in soil. Phytopathology 70:917-919.

Swoboda, C., and Pedersen, P. 2009. Effect of fungicide on soybean growth and yield. Agron. J. 101:352-356

Yadav, A. K., Singh, S., Dhyani, D., and Ahuja, P. S. 2011. A review on the improvement of stevia [Stevia rebaudiana (Bertoni)]. Can. J. Plant Sci. 91:1-27. 